\title{
Ergonomic Design of Street Lighting Must Be Based on Comfort and Security
}

\author{
I. Ketut Wijaya \\ Faculty of Electrical Engineering, Udayana University, Badung, Indonesia \\ Email address: \\ ketutgedewijaya@gmail.com
}

\section{To cite this article:}

I. Ketut Wijaya. Ergonomic Design of Street Lighting Must Be Based on Comfort and Security. Journal of Electrical and Electronic Engineering. Vol. 6, No. 3, 2018, pp. 80-87. doi: 10.11648/j.jeee.20180603.13

Received: July 3, 2018; Accepted: July 21, 2018; Published: August 23, 2018

\begin{abstract}
Street lighting is installed for the benefit of the community to assist in building the creative economy. Street lights in government efforts to create creativity help the family economy. The method used is to calculate the number of lamps used on the road with a distance of 1500 meters and provide a questionnaire of comfort and safety on the road users. Intake of light intensity data is done by calculating and measuring directly with the tool. The convenience and safety data were taken with by questionnaire based on a sample from the community. Existing data are related to each other and which is the source data is the light intensity data from the lights installed in the place of research done. All data will be analyzed with the light intensity as the determining factor of the resulting comfort and safety. Additional data are taken with from the data of the State Electricity Company (PLN) and from other sources that can strengthen the results of this study. Street Lighting is analyzed in an egonomic way to achieve effective, convenient, safe, healthy and efficient work. Result of research based on calculation 200 Watt lamp with 100 lumen / Watt with distance to road edge 3, 4, and 5 meter got 16.85, 14.94, and 13.08 Lux. Installation of street lights as far as 1500 meters which is divided into 44 poles. Electricity cost per year Rp. 49,871,111.28, -. The road lights after mounting provide a $30.7 \%$ increase in comfort and $34.93 \%$ security. The results of the analysis obtained are expected to provide results to be utilized by the community in relation as an additional family income. The results of such a study will provide a harmonious relationship to all interested parties between the government and the community in the lamp lighting installation environment to participate pay attention and cause a sense of having lamp street lighting for the next to can pay attention and keep. The results of the analysis also aims to provide a contribution to the Government's willingness to use this research model.
\end{abstract}

Keywords: Lamp Lighting Street, Ergonomic, Convenience, Security

\section{Introduction}

Lamp of street lighting is a means of increasing the desire to think outside in adding to the family economy. According to government records, lighting lamps can make Family Planning a success. Street lighting can work to function adds comfort as well as increase security. Street lighting can increase the activity for the community at night. Street lighting is expected to play an important role in improving the lives of people living around street lighting. The existence of street lighting makes environmental conditions more lively and people will be better able to take advantage of the situation to make creative efforts to add additional leverage to family life. Creative effort in question is to make canang (Banten) which will be sold in the morning to the
Balinese to other HINDU Balinese people who need it.

Lamp of street lighting needs to be designed for the purposes of community activities at night. At night people have started to do business by trading with out at midnight. Street lighting should be designed for the purposes of community activities at night with standards in accordance with applicable standards[14]. The communityt already wanted a street lighting. Street lights are expected to be installed so that the area is brighter than before. The community has made input to the officials of government. This area is quite potential to be developed because the community has the potential and the desire to grow through the resulting product. People in this area are used to doing night work to prepare for sale tomorrow morning to market. The market is a busy activity place at night. Night trading activities in the market must with lamp of 
street lighting that be sufficient to reduce the error. Trading at night is risky because there are so many cheats like counterfeit money. Lamp of street lightingis the solution in reducing the existing problems. Lamp of street lighting is needed to reduce unwanted things. Lamp of street lights installed at a distance of 1500 meters in Badung regency, Bali is intended for the benefit of the community in the activities at night [3]. This area needs street lighting to arouse community's intention to engage in supplementing family income. Communities utilize street lighting as an initial memotum in sustainability to be able to synergize with nature associated with supplementing family income, of course with sufficient light intensity quality [1, 2]. Street lighting is expected to encourage people to do business both day and night. Street lighting To be ergonomically designed to produce effective, comfortable, safe, healthy, and efficient performance improvements so as to reduce complaints, fatigue and possibly work-related stress $[10,11]$.

Research done with the installation of street lighting can add comfort and security. The street lights will be ergonomically designed in accordance with the wishes of the and governmental communities. The installation of lamp street lighting will target sustainable human development in advance creativity for the purpose of developing the family economy better. The design of street lighting should refer to the common interest between the community and the government. The community desperately needs street lighting and the government greatly appreciates the wishes of the community and is soon to be implemented [18].

\subsection{Problem Formulation}

From the above uaraian can be made the problem formulation as follows:

1. What is the magnitude of the light intensity corresponding to the area?

2. What is the operational cost per year?

3. Does the street lighting can add to the comfort?

4. Can street lighting improve security?

\subsection{Research Benefits}

The benefits of research are:

The benefit of this research is to provide understanding that street lighting can serve to keep society from unfavorable condition.

\subsection{How to Conduct Research}

1. Surveys to the field

2. Doing calculations on street lighting.

3. Measuring the intensity of light on street lighting.

4. Giving questionnaires to the public disekitas lapu street lighting.

5. Conducting analysis to be able to generate conclusions

\section{Material and Method}

The material in this research is the design of LPJ lamp in Badung regency, Bali with lots of lamps along the calculation of lights and the community around the street lighting as a sample.

The method used is designing and calculating and conducting street lighting analysis, to generate the required light intensity, provide comfort and safety questionnaires, by sampling which through the place.

\section{Results and Discussion}

\subsection{Results}

The result of this design is the result of the calculation and the result of the questionnaire which is done to get the result which is used for the base in the planning that will be installed as the, lamp of street lighting.

\subsubsection{Roads, Poles, Cables, Protection and Lights}

Lamp of street lighting design is done to find out how much intensity obtained. Design is required for installation purposes. street lighting.

1. Artery

2. Collector road

3. Local road

a. Image from lamppost

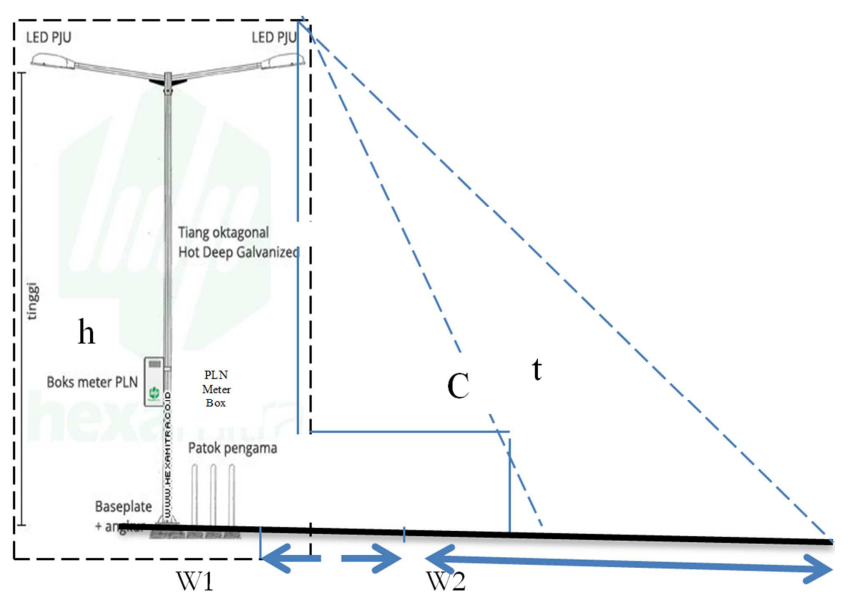

Figure 1. Pole Lamp of Street Lighting With Two-handed.

Where:

h: height of pole

c: horizontal distance of light to mid-way

$\mathrm{t}$ : The high of the lamp into the middle of the road

$\mathrm{W} 1$ : the pole distance to the end of the lamp

W2: the horizontal distance of the lamp to the end of the road.

To find the angle of the slope for the point of illumination

b. Cable

The cable used is a cable that has a National Standard Indonesia:

1. Cable NYA (PVC single insulated cable) with a maximum temperature of $700^{\circ} \mathrm{C}$.

2. NYM cable (multicore PVC-insulated cable is white)

3. NYY cable (multinomated PVC insulated cable is black) has a maximum ability of $1 \mathrm{KV}$.

c. Protection which used 
1. Type of protection (MCB) used if there is excessive flow current then this protection will open.

2. This type of protection is required to withstand shock currents (lightning strikes) or a fire that occurred (MCCB protection).

d. Lamp

Lamp that is used is a type of LED lights with the provision electric power from the lamp is 200 Watt with a pole height of 9 meters, either for one handlebar or two handlebar[21].

Lamp type: LED

Model: 200W (AC)

LED Power: 200 Watt

Light source 6 pcs high power LED

Voltage: $220 \mathrm{Vac} \sim 50 \mathrm{~Hz}-60 \mathrm{~Hz}$

Power Efficiency:> 0.9

LED Luminous Efficiency: 100Im / Watt

Efficiency of the Light: $>90 \%$

Light Color: Light Pure White / Warm

Light Beam 120-140 Degree

Housing die cast aluminum

Life Span:> 50000h

Dimension: $740 \times 242 \times 142(\mathrm{~mm})$

e. The calculation results

$$
\begin{gathered}
\mathrm{r}=\sqrt{h^{2}+c^{2}} \\
\text { SO } \operatorname{Cos} \emptyset=\frac{h}{t} \\
\varnothing=\operatorname{Cos}^{-1} \frac{h}{t}
\end{gathered}
$$

\subsubsection{Determined the Angle of Inclination with a 9 Meter Road Width}

Street lighting is mounted with span, with a slope angle. The angle of inclination is to determine how many degrees of slope of the lamp span will be installed. The tilt angle can also determine the intensity of the height at which the lamp is installed.

Table 1. Angle of Tilt.

\begin{tabular}{llll}
\hline \multirow{2}{*}{ No. } & \multirow{2}{*}{ High } & $\begin{array}{l}\text { Long of stem Hand } \\
\text { to the road 2.1 meters }\end{array}$ & Long of Stem Hand \\
\cline { 2 - 4 } & Pillar & Angle of Tilt (3.9 $\mathbf{~ m})$ & Angle of Tilt (3 m) \\
\hline 1 & 6 & 36.61 & 29.60 \\
2 & 7 & 32.36 & 25.70 \\
3 & 8 & 28.87 & 22.87 \\
4 & 9 & 19.33 & 20.36 \\
5 & 10 & 10.84 & 10.47 \\
6 & 11 & 11.72 & 11.43 \\
7 & 12 & 19.93 & 15.44 \\
\hline
\end{tabular}

Variations of lamp height from 6 to 12 meters are maximized in order to select the optimum height so that the ergonomic light intensity is obtained (ie at 9 meters height). For high lamp 10 meters upwards will get the light intensity is not good (SNI, 2008) while the height of 8 meters down, the height will be too low so that it will likely get a less good treatment from the people [17]. The most ideal 9 meter height is installed for street lighting in this place.

\subsubsection{Calculation Illumination at the Lamp Point to the End of the Road}

a. Calculation Currents

The large calculation of lights based on the selection, analysis, and needs with consideration in accordance with expectations and is not too extravagant.

The magnitude of K (efficiency) of lamp with a large angle of slope $\omega=4 \pi$

$$
\text { Then } i=\frac{K P}{\omega}=\frac{200 \times 100}{4 \times 3.14 \omega}=1592.36 \mathrm{Cd}
$$

b. Calculates Illumination at the Lamp Point to the End of the Road

The calculation of the intensity of light at the point of the road is done to obtain a certain intensity in the installation of street lighting, so it can be measured electrical energy used. [4]. The intensity of road lighting from the calculation will be the point where the next road lighting installation should be located [5].

(a) Calculating the illumination with a 3 meters road width:

$$
\begin{gathered}
\mathrm{r}=\sqrt{9^{2}+3^{2}}=9.49 \text { meters } \\
\text { So } \operatorname{Cos} \emptyset=\frac{h}{t}=\frac{9}{9.49}=0.95 \\
\emptyset=\operatorname{Cos}^{-1} 0.95=20.42^{0} \\
\operatorname{Er}=\frac{i}{r^{2}} \operatorname{Cos} \beta=\frac{1592.36}{9.49^{2}} \times \frac{9}{9.49}=\frac{1592.36}{90} \times 0.95=16.81 \mathrm{Lux}
\end{gathered}
$$

(b) Illumination at a distance of 4 meters

$$
\begin{gathered}
r=\sqrt{9^{2}+4^{2}}=9.85 \text { meters } \\
\text { So } \operatorname{Cos} \emptyset=\frac{h}{t}=\frac{9}{9.85}=0.91 \\
\varnothing=\operatorname{Cos}^{-1} 0.91=27.22^{0}
\end{gathered}
$$

$\operatorname{Er}=\frac{i}{r^{2}} \operatorname{Cos} \beta=\frac{1592.36}{9.85^{2}} \times \frac{9}{9.85}=\frac{1592.36}{97.02} \times 0.91=14.94 \mathrm{Lux}$

(c) Illumination at a distance of 5 meters (r)

$$
\begin{gathered}
\mathrm{r}=\sqrt{9^{2}+5^{2}}=10.29 \text { meters } \\
\text { So } \operatorname{Cos} \emptyset=\frac{h}{t}=\frac{9}{10.29}=0.87 \\
\varnothing=\operatorname{Cos}^{-1} 0.87=32.82^{0}
\end{gathered}
$$

$\mathrm{Er}=\frac{i}{r^{2}} \operatorname{Cos} \beta=\frac{1592.36}{10.29^{2}} \times \frac{9}{10.29}=\frac{1592.36}{105.88} \times 0.87=13.08 \mathrm{Lux}$

\subsubsection{Number of Lamp Points Required At 35 Meters Distance}

$$
\mathrm{B}=\frac{l}{s}+1=\frac{1500}{35}+1=44
$$

So the number of light points needed is 44 point lights.

For public roads with a length of 1500 meters can be installed lamps with a distance of 35 meters as many as 44 pieces of light poles. Lamp that will be installed as many as 
44 pieces with a distance of 35 meters is the result of calculations in the field. The results of this analysis may change in accordance with the common wish between the community and the government. But this change will not widen the distance but can be changed by minimizing the distance, because the intensity obtained is the maximum intensity.

\subsubsection{Calculation of Protection Used}

For the safety of street lighting is necessary to do a good calculation to get good results as well. Security calculations performed to keep the overload current short [16]. Protection due to lightning or caused by fallen trees installed special protection for lightning and tree protection. This condition should be installed a reliable installation for protection so that the street lights are safe as a result of lightning and fallen trees [9]. The calculations for the installation of lightning protection should also be done correctly with proper calculations. Protection due to overload and lightning must be an interconnected system. Both of these protections will be installed in the same place. The large calculation of the safety current used for the lamp is

Power used 44 pieces of light $=44 \times 200=8800$ Watt.

$$
\begin{gathered}
\mathrm{I}_{\mathrm{n}}=\frac{P}{V \operatorname{Cos} \emptyset}=\frac{44 \times 200}{220 \times 0.85}=47.06 \mathrm{~A} \\
\mathrm{I}_{\text {rating }}=\mathrm{K} \times \mathrm{I}_{\mathrm{n}}=125 \% \times \mathrm{I}_{\mathrm{n}}=125 \% \times 47 / 06=58.82 \mathrm{~A}
\end{gathered}
$$

Current APP rating flows is are

$$
\mathrm{I}_{\mathrm{n}}=\frac{P_{\text {total }}}{\sqrt{3} V \operatorname{Cos} \emptyset}=\frac{200 \times 44}{\sqrt{3} \times 380 \times 0.85}=8.68 \mathrm{~A}
$$

Flows rating on APP for,

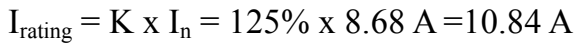

Based on the observation in the field, there is no protection under $16 \mathrm{~A}$, therefore protection is used with a with current strength of amount $16 \mathrm{~A}$.

\subsubsection{Calculation of Electrical Power Required Is}

The magnitude of the electric power used is to be able to determine the size of the protection and install the security devices used [12]. Calculation and data analysis is only necessary not for of security tools but also for cable channels. Calculation and evaluation of electrical power to be performed based on the amount of street lighting to be installed.The calculations and evaluations obtained shall be related to each other with installed safeguards [13]. Calculation and evaluation of electrical power to be performed based on the amount of street lighting to be installed. The calculations and evaluations obtained shall be related to each other with installed safeguards [13].

At $6 \mathrm{pm}$ the lights go on and off at 6:00 am the next morning without any blackouts [19]. Lights operate for 12 hours. The energy required for 12 hours of operation is:

$\mathrm{P}=200$ watts $\times 44$ Number of poles $\times \operatorname{Cos} \emptyset=8800 \times 0.85=$ 480 Watt

Then the power is connected to 44 lamps $=8.8 \mathrm{kVA}$.

\subsubsection{Electric Energy Which Used in a Day}

The use of electrical energy to street lighting depends on the use of lamps to be installed[13]. The measurement of electrical energy used by 44 street lighting lamps is energy per day and which is calculated its usage per 30 days to be paid to PT Perusahaan Listrik Negara Indonesia (PLN) )[20].

The fact the lights turn on in 12 hours for 44 pieces of lamp per day is,

$$
\begin{aligned}
\mathrm{W} & =(\mathrm{P} \times \mathrm{t}) / \operatorname{Cos} \emptyset \\
& =(200 \times 44 \times 12) / 0.85 \\
& =124,235.29 \mathrm{kWh} \text { per day }
\end{aligned}
$$

\subsubsection{In One Month the Energy Needed for 44 Lamps}

The use of electrical energy is an effort to return Tax from the government to the community and also in providing services to the community. Street lighting should be installed so that the community feel note by the government through the installation of street lighting. The use of street lighting will have an impact on the electrical energy used and also depends on Basic electricity rates (TDL) based on the Decision of the Minister of ESDM (2016) [15]. The total load cost of street lighting for one month sought by the formula 40 multiplied by the number of groups (Zone) multiplied by the load per month multiplied by the base rate of electricity (Rp./month) (40xZxSxTD).

$$
\mathrm{W} / \text { month }=124,235.29 \times 30 \text { days }=3,727.06 \mathrm{kWH}
$$

Based on the Regulation of the Minister of Energy and Mineral Resources of the Republic of Indonesia (ESDM) no. 28 year 2016, regarding the electricity tariff provided by PT Perusahaan Listrik Negara (PERSERO), that the electricity tariff for street lighting in the January-March 2018 tariff adjustment from $1300 \mathrm{VA}-200 \mathrm{kVA}=\mathrm{Rp} .1,049$, - / kWH. Electricity used in one month for 44 lamps are:

Table 2. Tariff of Electricity Usage.

\begin{tabular}{llllll}
\hline No. & Number of Pole & Number of Zones & $\begin{array}{l}\text { Power of Electricity (kWH/ } \\
\text { month) }\end{array}$ & $\begin{array}{l}\text { Basic Electricity Tariff } \\
\text { (TDL) (Rp./kWH) }\end{array}$ & Total Electricity Tariff (Rp.) \\
\hline 1 & T20 & 1 & $1,694.12$ & 1,049 & $1,777,131.88$ \\
2 & T20 & 1 & $1,694.12$ & 1,049 & $1,777,131.88$ \\
3 & T4 & 1 & 338.82 & 1,049 & $35,522.18$ \\
& & Total Cost & & & $2,309,685.94$ \\
\hline
\end{tabular}

To find the total cost of the load used by 44 lamps per month is the calculation of the load rate of PJU $=(40$ (flash time $) \mathrm{x}$ 
connected power $\mathrm{x}$ usage cost per $\mathrm{kWH})[21]$.

Table 3. Total the Cost of Load.

\begin{tabular}{llllll}
\hline No. & Number of Pole & Number of Zones & Load (S) / $\mathbf{k W h}$ & $\begin{array}{l}\text { Basic Electricity Tariff (TDL) } \\
\text { (Rp./kWH) }\end{array}$ & $\begin{array}{l}\text { Total Cost of Expenses (Rp.) }= \\
(\mathbf{4 0 x Z x S x T D L )}\end{array}$ \\
\hline 1 & T20 & 1 & 20 & 1,049 & 839,200 \\
2 & T20 & 1 & 20 & 1,049 & 839,200 \\
3 & T4 & 4 & 1,049 & 167,840 \\
& Total cost & & & $1,846,240$ \\
\hline
\end{tabular}

The operational cost of conventional PJU (Public Street Lighting) is monthly electricity bill (load charge + electricity usage rate) to be paid. So the monthly electricity bill is:

Total operational cost $/$ month $=$ Rp. 2,309,685.94 + Rp. $1,846,240=$ Rp. $4,155,925.94,-$

Total operational cost $/$ year $=$ Rp. $4,155,925.94 \times 12=R p$. $49,871,111.28,-$

\subsubsection{Comfort Analysis Results}

The result of convenience analysis was obtained by giving questionnaires to the community around street lighting. The results of the questionnaire analysis on the level of comfort performed on the community will provide a sense of comfort to produce products and can be sold.

Table 4. Results of Comfort Analysis Before and After Repair.

\begin{tabular}{|c|c|c|c|c|c|c|}
\hline Data & $\mathbf{N}$ & Mean & SD & Different & SD & $\mathbf{P}$ \\
\hline Before the lights are installed & 30 & 25.47 & 4.52 & \multirow{2}{*}{11.30} & \multirow{2}{*}{3.79} & \multirow[t]{2}{*}{0.00} \\
\hline After the lights are installed & 30 & 36.77 & 1.04 & & & \\
\hline
\end{tabular}

\subsubsection{Results of Security Analysis}

The level of security obtained be by the community by providing a security questionnaire will be able to see the level of security obtained community. Security is a very important factor in people's psyche and can foster other factors related to life and the life of the community. Security conditions before the installation of street lighting is very alarming, where at night people rarely out of the house. After being installed street lights of the community a lot of activity at night by making products that can be sold.

Table 5. Security Analysis Results.

\begin{tabular}{llllll}
\hline Data & N & Mean & SD & Different & PD \\
\hline Before the lights are installed & 30 & 19.13 & 2.56 & \multirow{2}{*}{9.97} & \multirow{2}{*}{0.00} \\
After the lights are installed & 30 & 29.10 & 2.67 & & \multirow{2}{*}{0.00} \\
\hline
\end{tabular}

\subsection{Discussion}

\subsubsection{Large of Intensity of Street Lamp Lighting}

The intensity of road lighting required in an area has been determined by a body and there are rules set by the Indonesian National Standards Agency 2016. Determination of use in connection with electrical energy has been regulated so that the use of electric energy energy will be very useful.

(a) Results of 200 Watt LED lamp analysis

Planning in the use of 200 Watt LED lamps with efficiency 100 lumen / Watt mounted with a pole height of 9 meters intended not to overheat. 200 Watt Lamp with 100 lumen / Watt efficiency cheaper than 200 Watt lamp with efficiency greater than 100 lumens / Watt and according to the economic point of view.[8]. 200 Watt LED lights with 100 lumens / Watt is enough to provide light intensity for street lighting at 3,4 , and 5 meters to the curb by $16.81,14.94$, and 13.08 Lux. 200 Watt LED lamp with 100 lumens / Watt is selected because it has good heat resistance compared to 100 Watt lamp with 100 lumen / Watt. 200 Watt LED lamp with 100 lumen / Watt is in accordance with Indonesian National Standard (SNI, 2008) [7].

200 Watt lamp with 100 lumens / Watt is chosen because it gives enough light intensity about 16.81 lux in span of 3 meter with angle $20.36^{\circ}$. At the light intensity conditions 16.81 lux is the lighting that meets the criteria of SNI, 2008 and meets the ergonomic requirements. The intensity of light is generated from the measurement with the lux meter which is the result of the calculation. The results of measurement should be the need to design street lighting to improve performance [10].

(b) The principles of ergonomics is: effective, comfortable, safe, healthy and efficient.

Ergonomics provides a solution that planning is the main one, because in planning it contains all the ideas to success. Design (planning) must be done in order to achieve the goals and intent of the idea that the planner wants. If a wellplanned job is ensured there are no additional costs and wasted work time. By applying ergonomic principles will lead to effective and efficient, comfort, healthy thinking and security incurred in life and work [10]. Implementation of ergonomics done at the start of the calculation, the selection of lights, the selection of reflectors, the distance between the lights and the selection of high lights and direction of the lamp.

Ergonomic design will produce a product that can provide 
problem solving without problems because the process:

1. The results of the design are the results of shared thoughts between the surrounding community and the Badung Regional Government (Badung Regional Government).

2. It is expected that community participation to maintain something that has been installed belongs to the community.

The selection and installation of street lighting should utilize reflectors that can make the lamp reflect back the desired light rays are. The choice of reflector must have the ability to direct the beam and focus of the lamp. Reflector is a very important factor in breaking the rays so that the rays are fixed on the intended target. A good replicator is a reflector that can provide maximum results in optimum light gain. The selection of the reflector should refer to the function and condition of the place where the reflector will be installed.

(c) The distance between the lamp

200 Watt Street Lamp with 100 lumens / Watt mounted with distance between lamp as far as 35 meter have got good result as expected is effective, comfortable, safe, and efficient seen from light intensity generated. Street lights installed as far as 1500 meters installed as many as 44 lamps (pole). Installation from lamp to lamp is expected to give each other light intensity and strengthen intensity at the meeting point of both points of light. At the distance between the points of light is selected based on the calculation results and the results of the optimal distance analysis on the lamp. Management in lamp placement is the result of an analysis of the conditions on which the lamp will be installed[19]. Light mounting analysis is also based on region conditions and optimum intensity requirements. All the results of distance analysis to be able to provide the optimum light intensity to achieve comfort and security in doing the activity.

(d) Height of lamp

The height of the lamp is chosen to get the intensity of light that is to desired. High of lamp mounted 9 meters with significant results provide a sense of comfort and safe on the community around. The intensity of the light from the results of calculations in accordance with ergonomic design will impact on life on all work activities. The height of the lamp is selected in relation to the rupian value to be planted on the lamp installation. The height of the lamp is analyzed and compared with the condition of the area on the installation of street lighting. Light height analysis is performed to obtain the ideal lamp height for the mounting area [18]. The result of analysis to get high ideal street lighting lamp is 9 meter with optimal light intensity equal to 16.81 lux with span length 3 meter with $20.36^{0}$ slope angle.

(e) Electrical load protection

Street lighting is divided into 3 groups. Installation of street lighting is divided into three Zones (groups) namely gruop 1 consists of 20 lights with one a protection of is 32 Ampere. The 2nd group consists of 20 lights with one protection of is 32 Ampere. The 3rd Group consists of 4 lights that comprise one of protection is 6 Amperes. Group division of street lighting should be done because if one group of madam lights due to weather conditions then not all street lighting will be extinguished [17]. The division is also intended to facilitate the work of the street lighting system if there is an improvement. Calculation analysis of the selection of protection from disruption to the electrical load is:

1. In groups 1 and 2 , the installation of 20 street lights has a reason easy to repairs with calculations,

$$
\begin{gathered}
\mathrm{I}_{\mathrm{n}}=\frac{P}{V \operatorname{Cos} \emptyset}=\frac{20 \times 200}{220 \times 0.85}=21.39 \mathrm{~A} \\
\mathrm{I}_{\text {rating }}=\mathrm{K} \times \mathrm{I}_{\mathrm{n}}=125 \% \times \mathrm{I}_{\mathrm{n}}=125 \% \times 21.39=26.74 \mathrm{~A}
\end{gathered}
$$

Thus, the appropriate load protection for the 20 street lamps is 32 A because the protection of electric loads in the market is only there are between $25 \mathrm{~A}$ and $32 \mathrm{~A}$.

2. Group 3 is installed 4 lamps of street lighting is for four street lights,

$$
\begin{gathered}
\mathrm{I}_{\mathrm{n}}=\frac{P}{V \cos \emptyset}=\frac{4 \times 200}{220 \times 0.85}=4.28 \mathrm{~A} \\
\mathrm{I}_{\text {rating }}={\mathrm{K} \times \mathrm{I}_{\mathrm{n}}}=125 \% \times \mathrm{I}_{\mathrm{n}}=125 \% \times 4.28=5.35 \mathrm{~A}
\end{gathered}
$$

Thus, the appropriate electrical load protection for 4 street lamps is $6 \mathrm{~A}$.

(f) Electricity operational cost per year

The electricity cost per month is derived from the electricity usage rate and total monthly load cost. PJU lamp with 44 lamps will pay Rp. 4,155,925.94, - per month.

Total operational cost per year is Rp. 49,871,111.28, -

From this operational cost value can be selected mounting on the distance between lampposts as far as 20, 25, 30, 35 meters or more. This selection depends on the financial condition of the region. The operational cost of electric power will depend on the distance between the lamps. The choice of spacing between these lamps should be based on the ability of light intensity from the minimal lamp to the furthest point. The closer the installation of street lighting will require more lights and it is certain that the operational costs will increase.

The cost of electric power is based on the hourly usage of the installed lamp multiplied by the number of lamps [201. The use of electrical power must be certain to know the total use of costs in the rupiah. The use of street lighting is expected to be optimal with optimal cost so that the cost does not become enlarged due to frequent late extinguish precisely. To reduce the risk of swelling the electricity payment is required to install the photocontrol device, so that the existing lighting becomes more efficient and thrifty [6]. This tool can turn on and / or turn off the electricity if the sun shines and turn on the lights when the sun is sinking automatically. Based on this the lights are required to use additional tools such as this for the risk of delays in reducing the use of electrical loads.

g. Street lights can add to the comfort of the activity

The results of the analysis show results that provide comfort activities outside the environment. Before the street lighting is installed very rarely the community activities outside the home. Street lights provide comfort for an outdoor activity. Convenience to the community is proven by 
the results of the questionnaire conducted at the research site. The result of the questionnaire showed significant result with the difference between before and after the street lighting lamp installe was $11.30 \pm 3.79$. These results indicate that people have a desire to perform activities at night to get out of the house to increase income in trade. Street lights inspire people to inspire outdoors. Street lighting can provide a sense of comfort to the community around the street lighting. The intensity of light coming out from the lamp of street lighting 16.81 lux has been able to provide comfort for the society in creative effort which is result of technical analysis and with economic goal have been reached.[8]. The added convenience of having street lighting makes the home page bright to make people react positively and reduce the hours of sleep to make something like cymbals (in Bali) to be sold in the market. As a result of street lighting of the community no longer sleep for long and the spirit of the community to do a small business and must done.

h. Streetlighting can improve security

Security in feelings can arise from the conditions due to street lighting and the environment becomes bright. The results of the questionnaire analysis conducted on the community around street lighting showed significant results and this can improve results the work of communit[10]. This result shows that the installed lamp of street lighting gives the result that security can be achieved by the presence of street lighting installed. The results of the questionnaire analysis performed amount $9.97 \pm 1.00$ were the results indicating that the security could be due to the presence of lamp of street light in ofg installed. Street lighting is a local government effort to provide a sense of security to the community. After a sense of security will arise courage to do business out of the house to interact at night. The results of this interaction will lead to the desire to participate in the business and continue with the creativity that produces. Creativity will develop with the formation of new business to be developed again into a larger one.

\subsubsection{The Strengths and Weaknesses of the Article}

Strengths in this study:

This research is done correctly, because there has been no research that connects ergonomics with a study of the existing lighting. Here the function of ergonomics is man working and utilizing the results of the work of others for the interests and needs of life with the purpose of comfort and security.

Weaknesses in this study:

The weaknesses in this study are:

1. Permission to obtain data from authorized officers.

2. Distance of research with residence researchers far enough

3. Requires at least 2 or more persons in the study

\subsubsection{Updates on Research}

The Update on This Research Is That This Calculation Can Be Changed According to the Willingness of the Researcher. More The Brighter The Lamp Are Installed Will

\section{Cause More Comfortable and More Secure}

\subsubsection{Acknowledged}

Thanks to all my friends at UNUD's electrical engineering laboratory who assisted in this research. Personally and as the lead researcher (as the sole Writer in this research) I thank all those who helped so this research can be resolved.

\section{Conclusion and Suggestions}

\subsection{Conclusion}

From the above Description it can be concluded:

This research can be used by all people to envisage the installation of street lighting to obtain optimal results expected for the benefit of the community. The results obtained ergonomically can see the real condition of the community before and after the installation of street lighting in the vicinity of street lighting installed. The intensity of light can affect the results of the questionnaire so as to change the level of community life. The results of the ergonomic light design analysis of street lighting can provide effective, convenient, safe, healthy and efficient results in doing the job without having to make the next fatal mistake.

\subsection{Suggestion}

Suggestions in this research are:

This research is expected to assist all involved and so that each design can produce the comfort and security of the design user's and is a meaningful purpose of this research. This study is also expected can be meaningful and used throughout the territory of the State of Indonesia as human beings should be respected. This research model should be done by measurable and through step by step in a structured and through the rules of the grammar. The design should refer to the ergonomic system in order to achieve a relationship between all the holder sticks (installers, proponents and communities in the street lighting installations). Design, calculation and analysis should refer to the existing standard (SNI) to get a large intensity of light illumination. Usefulness of the Design, calculation and analysis is to obtain a enough power lights so as not to use the lights are too large, so the listrk used is not expensive.

\section{References}

[1] Andreas, Ricky. 2015. Analysis of Lighting Quality And Operational Costs Lighting Street Street Type And Led Sed On Toll Road Srondol-Krapyak By Using Dialux Evo. Final Project: Semarang: Electrical Engineering, Diponegoro University, Accessed 20 April 2017.

[2] Asnal Effendi dan, Asep Suryana, 2013. Evaluation of Streetlight Lighting System In Sungai Bahar District. Journal of Electrical Engineering ITP, Volume 2 No. 2; July 2013. Accessed 18 April 2018.

[3] Badung District Government, 2018. Road Lighting Planning. Taken 21 April 2017. 
[4] Basic Theory of Public Street Lighting and Electrical Energy Measurement volumes 1. University of North Sumatra. Accessed 20 April 2017.

[5] Christian D., Lestari P. (1991). Lighting Technique and Lighting Layout. Artolite Grasindo. Basic Theory of Public Street Lighting Accessed Retrieved 27 April 2017.

[6] Dinas Cipta Karya Kabupaten Jember. 2013. Existing condition of street lighting. in Jember. Accessed 20 April 2017.

[7] Direktorat Jenderal Bina Marga, 1991. Specification Lamp Street Lighting in the Urban, (Jakarta). National Standardization Body, 2008. SNI 7391 Lighting Information on Urban Roads, Jakarta: BSN. Accessed 22 April 2017.

[8] Eni Satria, 2018. Comparative Planning Technically And Economically In Electric Lighting System For Conventional Public Road And Solar Cell. Accessed 25 May 2017.

[9] Harten P. Van, 1981. Current Flow Installation 2, Bandung: Bina Cipta, Retrieved 28 April 2017.

[10] I Ketut Wijaya, 2011. Ergonomic Redesign Of Computer Laboratory To Improve Performance And Efficiency Power Electrics In Electrical Engineering Computer Laboratory At Udayana University. Dissertation.

[11] I Ketut Wijaya, 2012. Effects of Temperature, the Lighting, Workload, Noise Against Eye Fatigue, General Fatigue and Stress Affect Learning Outcomes the Student Computer Users, Journal. Journal.

[12] Kadir, Abdul 2000. Distribution and Utilization of Electric Power. Jakarta: University of Indonesia (UI-Press). Dissertation.

[13] Mayretta, Santa. 2014. Evaluation of Street Lighting (Road Case Study W. R Supratman Bandung, West Java). Thesis. Yogyakarta: Civil Engineering, Atma Jaya University Yogyakarta. Accessed 25 May 2017.

[14] Peraturan menteri energi dan sumber daya mineral No. 30 tahun 2016. About Electricity Tariff Provided By Company Persero (Persero) Pt Perusahaan Listrik Negara. Accessed 25 May 2017.
[15] Prabu, 2009. System and Standards. Lighting of Space, Accessed December 27, 2017.

[16] PUIL 2011 SNI 040225-2011. Accessed 25 May 2017.

[17] SNI 7391: 2008 Specification of street lighting Electricity utilization technique, volume 1. Accessed 25 May 2017.

[18] Sri Pringatun, Karnoto, M. Toni Prasetyo, 2011. Comparative Analysis of Toll Road Lighting. Media Elektrik, Vol. 4 No. 1, June 2011. Accessed 25 May 2017.

[19] Wibawa, Unggul, 2004. Management of Industry-II, Malang: Department of Electrical Engineering Universitas Brawijaya. Accessed 25 May 2017.

[20] www.cahaya-led.com/sumber-listrik-plnac220v/148pju-112wfer104.html. Accessed December 27, 2017.

[21] www.cahaya-led.com/led-street-light-lampu-pju-/146pju-28wfer101.html. Accessed December 27, 2017.

\section{Biography}

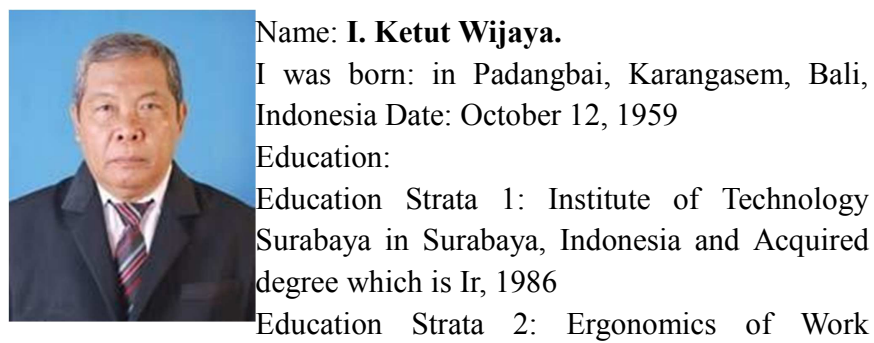
Physiology Udayana University in Denpasar, Bali, Indonesia, and degree which obtained is M. Erg (Master Ergonomics), 2007

Education Strata 3: Ergonomics of Work Physiology Udayana University in Denpasar, Bali, Indonesia, and degree which obtained is Dr (Doctor), in 2011

Worked as a lecturer at the Faculty of Electrical Engineering University of Udayana Badung, Indonesia from 1987 to the present. 